\title{
Basal Cell Hyperplasia in the Peripheral Zone of the Prostate
}

\author{
Phataraporn Thorson, M.D., Paul E. Swanson, M.D., Robin T. Vollmer, M.D., \\ Peter A. Humphrey, M.D., Ph.D. \\ Lauren V. Ackerman Laboratory of Surgical Pathology, Washington University Medical Center, St. Louis, \\ Missouri (PT, PES, PAH), and Veterans Administration and Duke University Medical Centers, Durham, \\ North Carolina (RTV)
}

Basal cell hyperplasia in the prostate is often viewed as a transition zone proliferation, related to usual, nodular glandular, and stromal hyperplasia. Basal cell hyperplasia in the prostatic peripheral zone, the most common site for development of prostatic intraepithelial neoplasia and carcinoma, has not been previously characterized. We characterized the incidence and histomorphological attributes of basal cell hyperplasia in a series of $\mathbf{5 0 0}$ consecutive sextant needle core biopsy samples and in 26 completely embedded prostate glands from radical prostatectomy specimens. Comparative proliferation indices (by MIB-1 staining) and apoptotic indices (by TUNEL labeling) were quantitated for peripheral zone versus transition zone basal cell hyperplasia versus normal basal cells. The incidence of basal cell hyperplasia in prostate needle biopsy tissue was $10.2 \%$ (51 of 500 cases). Usual basal cell hyperplasia was detected in $8.2 \%$ of the 500 cases, and basal cell hyperplasia with prominent nucleoli, in $2.0 \%$ of cases. Basal cell hyperplasia in needle biopsy tissue was typically focal and associated with inflammation, which was usually lymphocytic, in $84 \%$ of cases. Peripheral zone basal cell hyperplasia was found in $\mathbf{2 3 \%}$ of whole prostate glands. Peripheral zone basal cell hyperplasia was not observed to be in direct physical continuity with intraepithelial or invasive neoplasia. Peripheral zone and transition zone basal cell hyperplasia exhibited similar mean proliferation and apoptotic indices, at $1 \%$ and

\footnotetext{
Copyright (C) 2003 by The United States and Canadian Academy of Pathology, Inc.

VOL. 16, NO. 6, P. 598, 2003 Printed in the U.S.A

Date of acceptance: March 5, 2003.

Supported by an award (to PAH) from CaP CURE (Association for the Cure of Cancer of the Prostate).

PT is currently at Severance and Associates, a division of Ameripath, San Antonio, Texas; PES is currently at University of Washington Medical Center, Seattle, Washington.

Address reprint requests to: Peter A. Humphrey, M.D., Ph.D., Department of Pathology and Immunology, Campus Box 8118, Washington University Medical Center, 660 South Euclid Avenue, St. Louis, MO 63110; fax: 314-747-2040; e-mail: humphrey@path.wustl.edu.

DOI: $10.1097 / 01 . M P .0000073526 .59270 .6 \mathrm{E}$
}

$0.07 \%$, respectively. This proliferation index was elevated, and apoptotic index was decreased, relative to normal basal cells $\left(P=1 \times 10^{-7}\right)$. Basal cell hyperplasia in the peripheral zone is present in a significant minority of prostate needle biopsy samples and whole prostate glands. The presence of prominent nucleoli in basal cell hyperplasia may cause diagnostic concern for a neoplastic proliferation. The increase in cell number in basal cell hyperplasia appears to be due to a coordinate increase in proliferation index coupled with a diminished apoptotic index. The presence of inflammation in the majority of basal cell hyperplasia foci suggests that peripheral zone basal cell hyperplasia in untreated patients may represent a stereotyped response to injury such as that sustained because of inflammation.

KEY WORDS: Basal cell, Hyperplasia, Inflammation, Peripheral zone, Prostate.

Mod Pathol 2003;16(6):598-606

Basal cell hyperplasia is occasionally a component of untreated usual, nodular, glandular and stromal hyperplasia, or benign prostatic hyperplasia, which arises in the transition zone in the prostate (1-14). Initially thought to be rare (1), the incidence of basal cell hyperplasia in the setting of usual, nodular hyperplasia has been reported to range from 3.1 to $8.9 \%(2,5,10,13,15)$. It has been noted that basal cell hyperplasia may be atrophy associated and found in the peripheral zone (11), but basal cell hyperplasia arising in the peripheral zone of the prostate has not been previously characterized. The peripheral zone of the prostate is the most common site of development of prostatic intraepithelial neoplasia and carcinoma and is specifically targeted in clinical sampling of the prostate by transrectal needle core biopsy. Diagnostic recognition of basal cell hyperplasia in the peripheral zone is important because it may be mistaken for prostatic intraepithelial neoplasia or adenocarcinoma. 
The aim of this investigation was to characterize, in 526 cases, the incidence, histomorphological features, proliferation index, and apoptotic index of basal cell hyperplasia in the peripheral zone of the prostate.

\section{MATERIALS AND METHODS}

Five hundred twenty-six prostate tissue samples were examined in this investigation. The study included 500 consecutive prostate needle biopsies performed at Barnes-Jewish Hospital during 1994. All H\&E-stained slides from these cases were reviewed under light microscopy for the presence of basal cell proliferation by two of the authors (PT and $\mathrm{PAH}$ ). Only cases designated as peripheral zone biopsies were evaluated for the presence of basal cell proliferation. None of these patients had a diagnosis of prostatic adenocarcinoma before these biopsies. None of the patients are known to have received previous hormonal or radiation therapy. The mean patient age was 64 years (range, 40 to $88 \mathrm{y})$. Each case was composed of 3 to 16 slides (mean $=8$ ) and comprised $\geq 3$ levels per block, stained with hematoxylin and eosin and prepared from routinely formalin-fixed, paraffin-embedded tissue.

The biopsy specimens were evaluated for usual (typical or ordinary) basal cell hyperplasia and atypical basal cell hyperplasia on previously reported criteria $(4,5)$. Briefly, usual basal cell hyperplasia was composed of proliferation of basal cells, with two or more basal cell layers, at the periphery of prostatic glands and acini (5). We excluded glands with a single, prominent, basal cell layer. Atypical basal cell hyperplasia was defined as basal cell hyperplasia with $>10 \%$ of nuclei containing prominent nucleoli. Nucleolar size was not morphometrically determined for these prominent nucleoli but was roughly $1-3 \mu \mathrm{m}$. The incidence of atrophy, squamous metaplasia, transitional cell metaplasia, high-grade prostatic intraepithelial neoplasia, and adenocarcinoma was also determined in these needle biopsy cases. Cases were assessed for mitotic figures, intraluminal wispy blue mucin, necrotic intraluminal debris, individual cell necrosis, clear cell features, and associated inflammation; high-grade prostatic intraepithelial neoplasia; and adenocarcinoma. We analyzed the association of basal cell hyperplasia with high-grade prostatic intraepithelial neoplasia and carcinoma by $\chi^{2}$, with a $P$ value of $<.05$ considered significant.

Peripheral zone and transition zone basal cell proliferations were also evaluated in 26 consecutive, completely embedded prostate glands from radical prostatectomies performed in 1996 at Barnes-Jewish Hospital, as treatment for biopsy- proven, clinically localized prostate carcinoma. None of the patients received preoperative hormonal or radiation therapy. All slides were reviewed for the presence of basal cell hyperplasia in the peripheral zone and transition zones of the prostate gland. The size of basal cell hyperplasia foci was quantitated as greatest dimension in linear millimeters, as measured with an ocular micrometer, and as number of basal cell hyperplasia glands per focus. Associations of basal cell hyperplasia with inflammation, benign prostatic hyperplasia nodules, high-grade prostatic intraepithelial neoplasia, and adenocarcinoma were recorded.

Immunohistochemical staining for high-molecular weight cytokeratin and Ki-67 was performed in all cases of basal cell hyperplasia. Staining for highmolecular weight cytokeratin was performed using mouse monoclonal antibody $34 \beta E 12$ (at 1:150 dilution; DAKO, Carpenteria, CA), reactive against Moll catalog cytokeratins $1,5,10$, and 14 and was done to confirm basal cell identity in all cases designated as basal cell hyperplasia. Staining for antigen Ki-67 was performed on sections from the radical prostatectomy tissue using antibody MIB-1 (at 1:100 dilution; Newcastle upon Tyne, UK) and was done to quantitate proliferation index.

Immunohistochemical reactions were performed after microwave irradiation of tissue sections for 8 (34 $\beta$ E12) or 12 (MIB-1) minutes. We used a modified avidin-biotin-peroxidase complex method (VectaStain ABC Elite Mouse Universal Kit; Vector Laboratories, Burlingame, CA) and developed the stain by immersion of the slides in metalcomplexed 3,3'-diaminobenzidine tetrahydrochoride (Pierce Chemicals, diluted 1:10 from commercial stock, mixed with commercially prepared peroxide substrate) for $\leq 10$ minutes. Three hundred nuclei of basal cells in normal prostate gland peripheral zone and transition zone and in areas of basal cell hyperplasia in peripheral zone and transition zone were assessed. The number of positively stained nuclei was recorded, yielding a proliferation index as percentage of cells staining for each of the four categories.

Apoptotic index was quantitated by counting cells in sections of radical prostatectomy tissue stained by TdT (terminal deoxynucleotidyl transferase)mediated dUTP (deoxyuridinetriphosphate)-biotin nick-end labeling (TUNEL). TUNEL staining was performed using the ApopTag kit (ONCOR, Gaithersburg, $\mathrm{MD}$ ), modified from the manufacturer's recommendations (by substituting hematoxylin as the counterstain). An apoptotic index for each of the four categories (normal peripheral zone basal cells, normal transition zone basal cells, basal cell hyperplasia of peripheral zone, and basal cell hyperplasia of transition zone) was generated by determining the number 
of positively stained basal cell nuclei per 300 basal cell nuclei.

To test for a significant effect of location and basal cell hyperplasia status on either proliferation index or apoptotic index, we used the general linear model with a Poisson link function, because both dependent variables were counted data.

\section{RESULTS}

\section{Basal Cell Hyperplasia in Needle Biopsy Tissue}

The incidence of basal cell hyperplasia in the 500 peripheral zone needle biopsy cases was $51 / 500$, or $10.2 \%$ (Table 1). Most cases were usual basal cell hyperplasia, with an incidence of $41 / 500$ or $8.2 \%$, whereas only 10 cases of atypical basal cell hyperplasia were identified. Usual basal cell hyperplasia often displayed a circumferential proliferation of basal cells, with at least two cell layers (Fig. 1). The basal cells had small and round to slightly ovoid nuclei, with absent to inconspicuous nucleoli. Preservation of an inner layer of luminal cells was often noted (Fig. 2). A solid nested pattern, with or without a small central space, was also evident (Fig. 3). Atypical basal cell hyperplasia was diagnosed if $>10 \%$ of the basal cells exhibited prominent nucleoli. Intraluminal wispy blue mucin and necrotic intraluminal debris were not found in basal cell hyperplasia. Mitotic figures, individual cell necrosis, and clear cell cytoplasmic features were rare.

Inflammation, usually chronic in nature, was commonly associated with basal cell hyperplasia in peripheral core needle biopsy tissue (Fig. 4). Chronic inflammation was in direct physical association in $58 \%$ of cases of usual basal cell hyperplasia and $78 \%$ of cases of atypical basal cell hyperplasia. Acute inflammation was found associated with usual basal cell hyperplasia in $12 \%$ of cases and with atypical basal cell hyperplasia in $11 \%$ of cases.

No direct physical continuity was noted between basal cell hyperplasia or atypical basal cell hyperplasia and high-grade prostatic intraepithelial neoplasia or adenocarcinoma. There was no statistically significant difference in the frequency of highgrade prostatic intraepithelial neoplasia in cases with $4 / 51$ (or $7.8 \%$ ) versus those without basal cell

TABLE 1. Incidence of Basal Cell Hyperplasia and Other Diagnoses in 500 Prostate Needle Biopsy Cases

\begin{tabular}{lc}
\hline \multicolumn{1}{c}{ Histologic Finding } & Incidence \\
\hline Basal cell hyperplasia, usual & $41 / 500(8.2 \%)$ \\
Basal cell hyperplasia with prominent nucleoli & $10 / 500(2.0 \%)$ \\
Atrophy & $460 / 500(92.0 \%)$ \\
Transitional cell metaplasia & $69 / 500(13.8 \%)$ \\
Squamous metaplasia & $5 / 500(1.0 \%)$ \\
Isolated high-grade PIN $^{1}$ & $26 / 500(5.2 \%)$ \\
Adenocarcinoma & $124 / 500(24.8 \%)$ \\
\hline
\end{tabular}

${ }^{1} \mathrm{PIN}=$ prostatic intraepithelial neoplasia. hyperplasia $(42 / 444$ or $9.4 \% ; P=0.92)$. Cases with basal cell hyperplasia were significantly less likely to harbor adenocarcinoma (4/51 or $7.8 \%$ ) compared with cases without basal cell hyperplasia (120/449 or $26.7 \%$; $P=.0053)$.

\section{Basal Cell Hyperplasia in Whole Prostate Glands}

Twenty-one of 26 whole prostates $(80 \%)$ had foci of basal cell hyperplasia. Basal cell hyperplasia was much more common in the transition zone, with $73 \%$ of cases involved, compared with peripheral zone basal cell hyperplasia, which was identified in $23 \%$ of cases. All cases of basal cell hyperplasia in the whole gland were usual basal cell hyperplasia, except for one case of atypical basal cell hyperplasia in the transition zone (Fig. 5).

Histologically, basal cell hyperplasia was similar in the transition zone compared with the peripheral zone, except for the occurrence of transition zone basal cell hyperplasia in benign prostatic hyperplasia nodules and the association with atrophy in several cases of peripheral zone basal cell hyperplasia (Figs. 6, 7). The size of the basal cell hyperplasia foci ranged from $1-4 \mathrm{~mm}$ in greatest diameter and from one to four or five glands in each focus. Inflammation was present in a similar majority of cases of basal cell hyperplasia in the transition zone (63\% of cases; Fig. 8) and the peripheral zone (67\% of cases). No direct continuity between basal cell hyperplasia and highgrade prostatic intraepithelial neoplasia or adenocarcinoma was seen.

The proliferation and apoptotic indices were extremely low for both normal and hyperplastic basal cells in both the transition and peripheral zones (Table 2). The proliferation indices and the apoptotic indices for basal cell hyperplasia in the transition and peripheral zones were similar. Compared with normal basal cells, the proliferation index of basal cell hyperplasia was significantly higher $(P$ value $=1 \times 10^{-7}$ ), and the apoptotic index of basal cell hyperplasia was significantly lower $(P$ value $=1$ $\left.\times 10^{-7}\right)$.

\section{DISCUSSION}

The data presented here indicate that basal cell hyperplasia is not exclusively a transition zone process associated with nodular hyperplasia (benign prostatic hyperplasia) but rather may also be identified in tissue samples from the peripheral zone of the prostate, including $10 \%$ of needle core biopsy samples from the peripheral zone. This finding has diagnostic implications because basal cell hyperplasia, particularly basal cell hyperplasia with prominent nucleoli, or atypical basal cell hyperplasia, may be misdiagnosed under the light micro- 


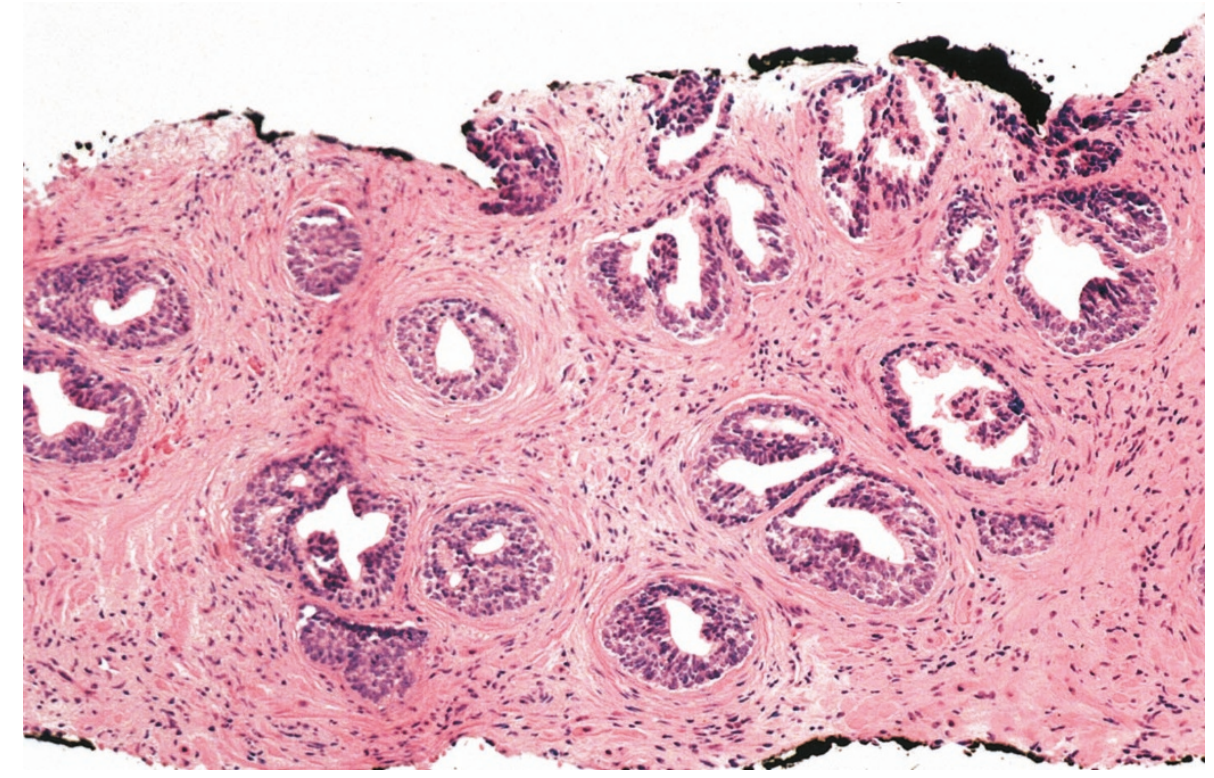

FIGURE 1. Basal cell hyperplasia in needle biopsy tissue.

scope as high-grade prostatic intraepithelial neoplasia or adenocarcinoma $(10,11,16,17)$. Indeed, in one study (17), fully $26 \%$ of cases misdiagnosed as carcinoma in TURP chips were basal cell hyperplasia cases.

It has been recognized that foci of basal cell hyperplasia may be found in the peripheral zone, and this basal cell hyperplasia was designated as atrophy associated (11). Atrophy-associated basal cell hyperplasia can be seen in prostatic tissue in patients treated with androgen-deprivation therapy, radiation therapy, and cryosurgery $(15,18-$ 26), but the zonal location of the basal cell hyperplasia was not specified. We detected atrophy- associated basal cell hyperplasia in the peripheral zone in a few cases, but the striking finding in our series of untreated patients was that peripheral zone basal cell hyperplasia was commonly associated with inflammation, especially lymphocytic inflammation. The association of basal cell hyperplasia with lymphocytic chronic inflammatory cell infiltrates has been previously reported $(4,5)$.

The incidence of basal cell hyperplasia in untreated patients has previously been reported to range from 3 to $9 \%(2,5,10,13,15)$, but the specific incidence in prostate needle biopsy tissue and in the peripheral zone had not been previously defined. Here, we report a basal cell hyperplasia inci-

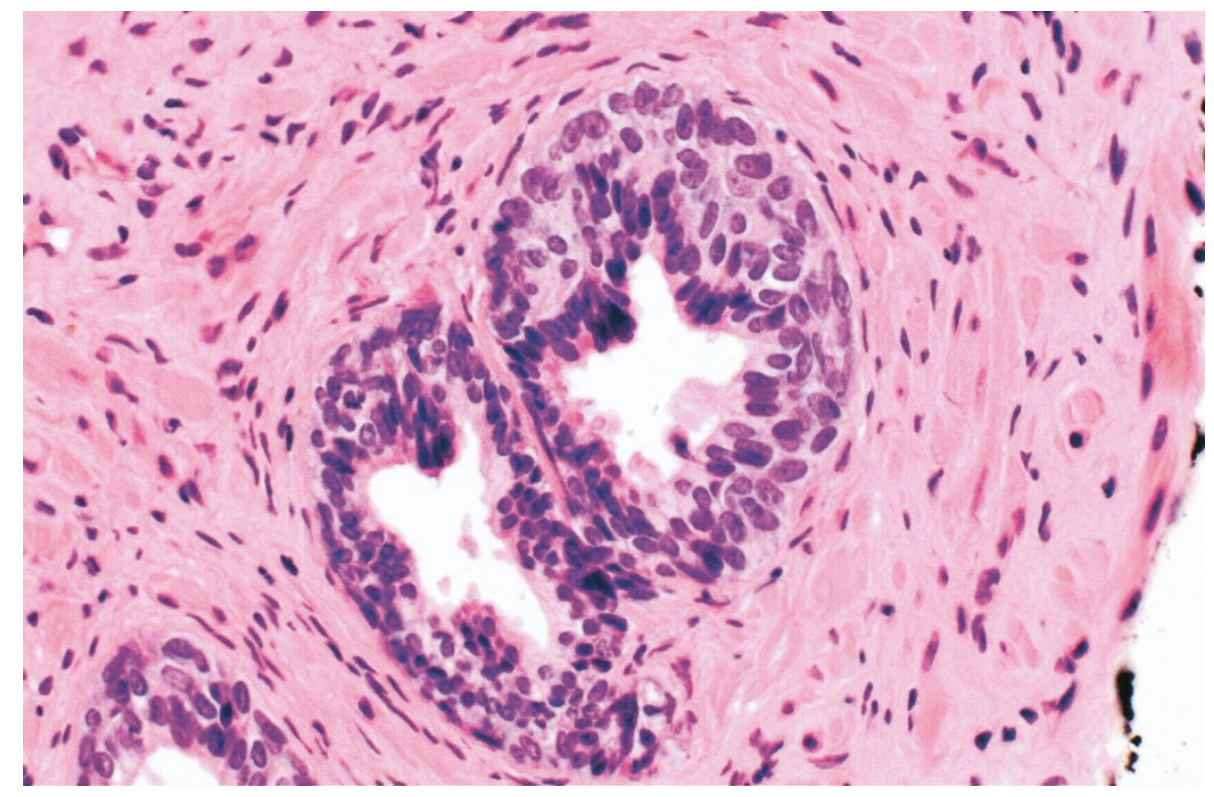

FIGURE 2. Basal cell proliferation underneath secretory, luminal cell layer. 


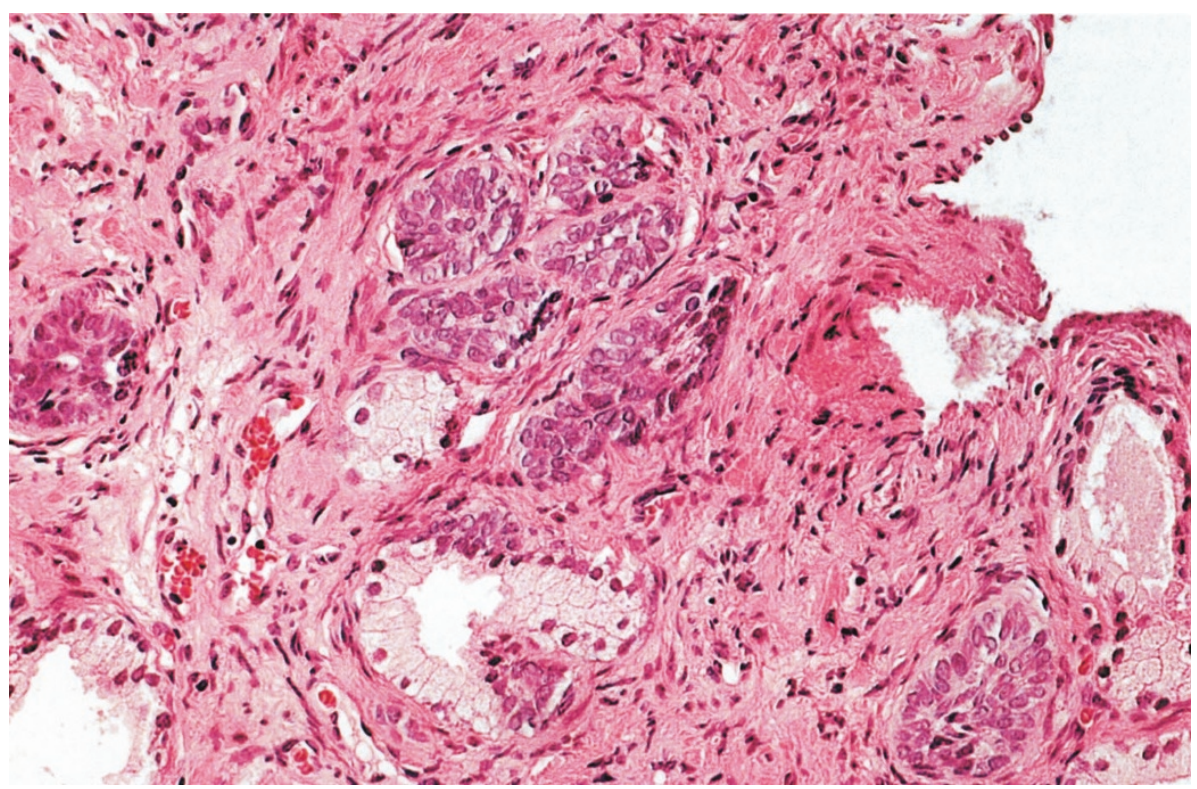

FIGURE 3. Solid nests of basal cell hyperplasia in prostate needle biopsy tissue.

dence of $10 \%$ in a large series of 500 consecutive peripheral zone needle biopsy cases. Also not previously known was the incidence of basal cell hyperplasia with prominent nucleoli; here we found $2 \%$ of prostate needle biopsy cases with this proliferation. It is possible that these figures of $2-10 \%$ could represent an overestimate, if the needle biopsies labeled as being from the peripheral zone were instead taken from the transition zone. This could happen if large transition zone nodules of usual hyperplasia compressed the peripheral zone, such that the needle passed through a thinned peripheral zone before biopsy sampling. We did con- firm the existence of basal cell hyperplasia in the peripheral zone of the prostate by examination of sections from completely embedded prostate glands from radical prostatectomy specimens. As one would expect, the incidence was higher in the whole glands (23\%) versus the much smaller needle biopsy tissue samples.

Peripheral zone and transition zone basal cell hyperplasia were quite similar histologically. The major difference was that transition zone basal cell hyperplasia was often associated with nodular, glandular, and stromal hyperplasia. The basal cell proliferations in both zones were quite focal and
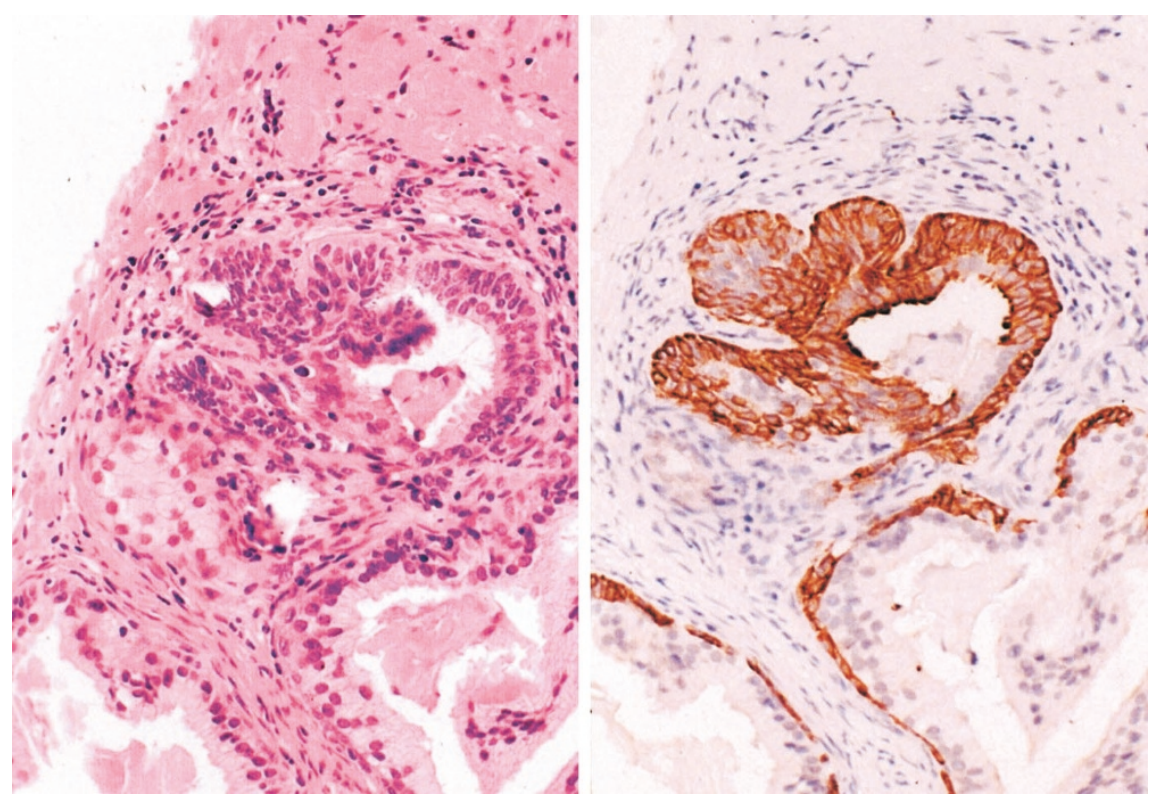

FIGURE 4. Basal cell hyperplasia in needle biopsy tissue, associated with chronic inflammation. Confirmation of basal cell identity was accomplished by immunohistochemical staining with antibody 34 betaE12 (right panel). 


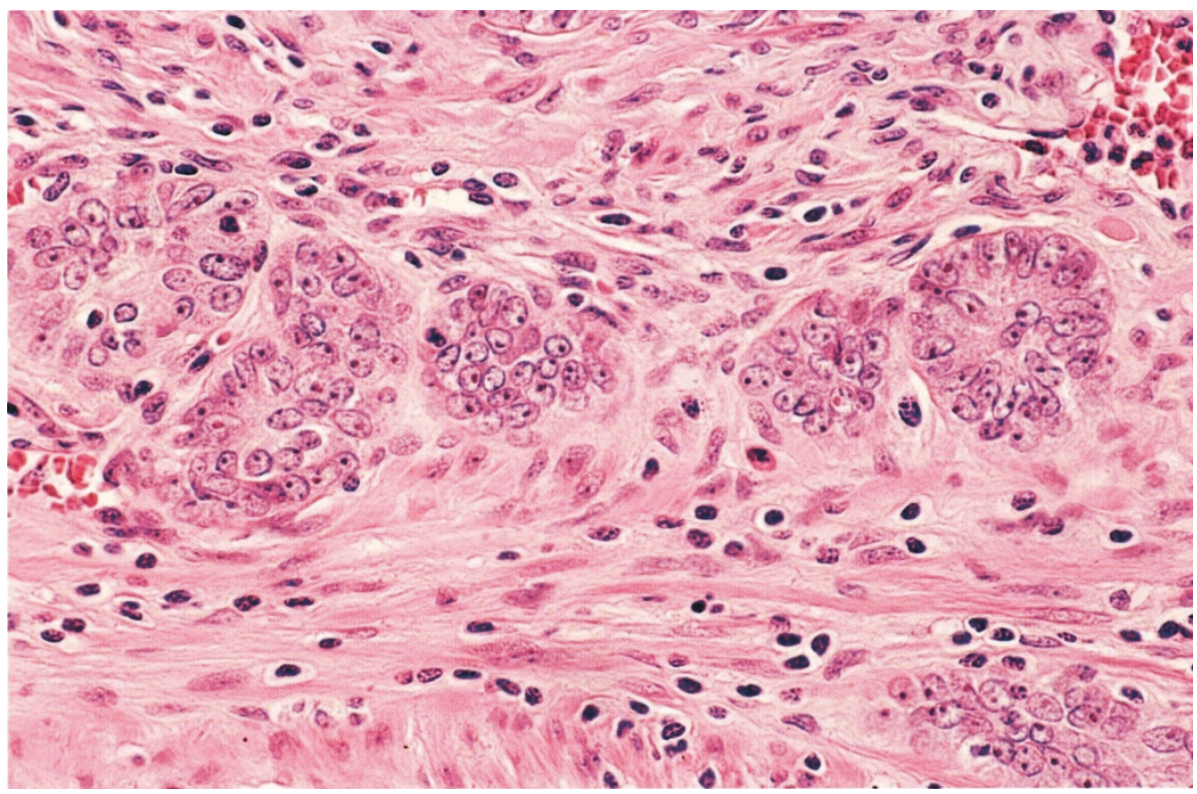

FIGURE 5. Basal cell hyperplasia with prominent nucleoli (also known as atypical basal cell hyperplasia).

did not form masses, as may be observed in other basaloid proliferations in the prostate, such as nodular basal cell hyperplasia, basal cell adenoma, adenoid basal cell tumor, and basaloid carcinomas. Architecturally, we observed previously reported configurations of basal cell growth, including tubular and solid patterns $(4,5,7,11)$. The most alarming cytological finding is the enlarged nucleoli in basal cell hyperplasia with prominent nucleoli.

The differential diagnosis for basal cell hyperplasia with prominent nucleoli includes a number of entities. A constellation of features distinguish basal cell hyperplasia with prominent nucleoli from high- grade prostatic intraepithelial neoplasia, including architecture, the presence of the atypical basal cells underneath benign secretory nuclei, the smaller and rounder glands, solid nests, absence of prostate specific antigen and prostatic acid phosphatase immunoreactivity in the atypical cells, and the presence of high molecular weight cytokeratin, as detected by $34 \beta \mathrm{E} 12$ immunostaining, in the atypical cells $(4,5)$. We confirmed basal cell identify in all of our cases of basal cell hyperplasia, with and without nucleoli, by $34 \beta \mathrm{E} 12$ immunohistochemical staining. The differential diagnosis of basal cell hyperplasia with prominent nucleoli and infiltrating

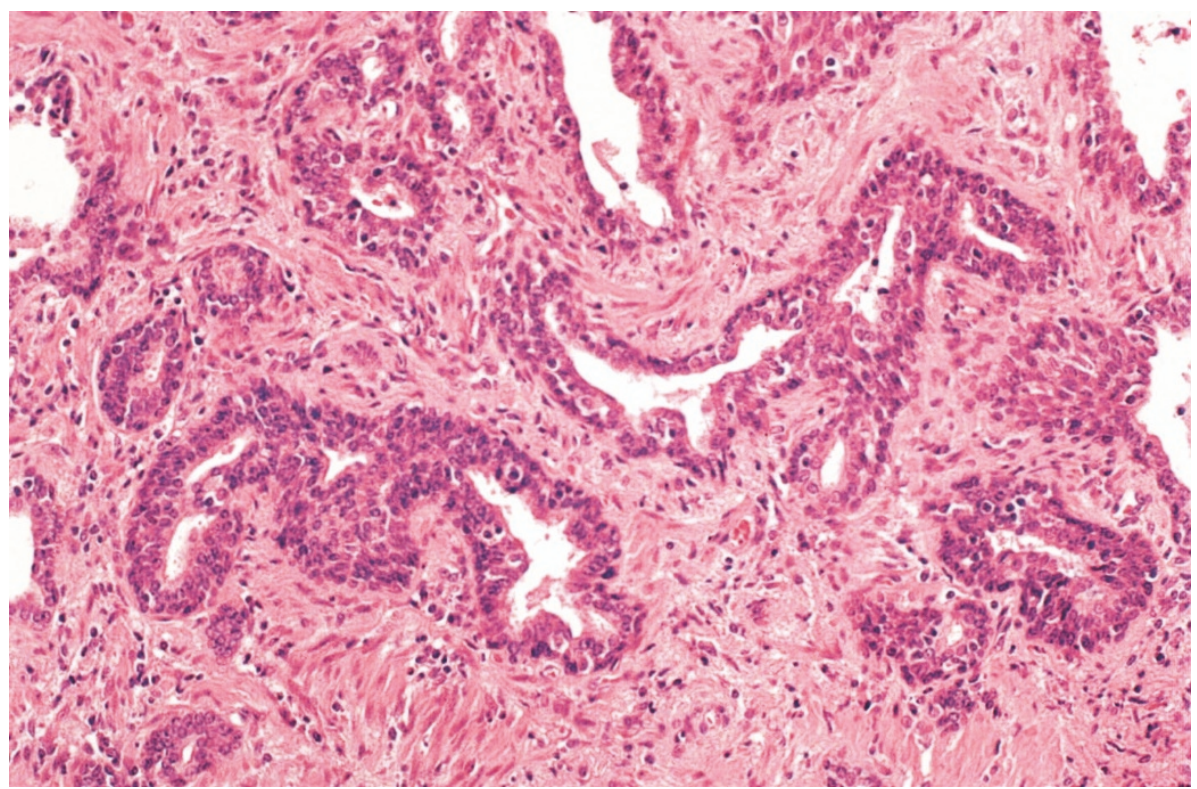

FIGURE 6. Peripheral zone basal cell hyperplasia in radical prostatectomy tissue. The glands have atrophic features and there is an associated lymphocytic infiltrate. 


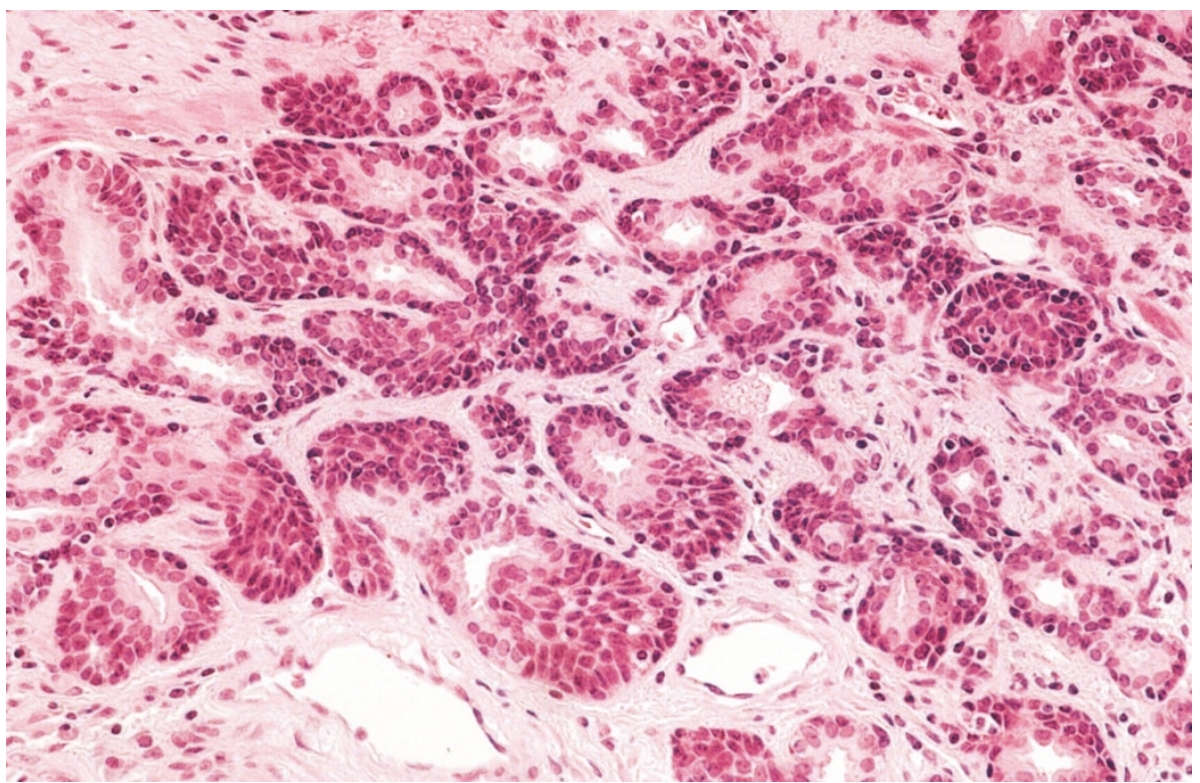

FIGURE 7. Basal cell hyperplasia in the peripheral zone of a radical prostatectomy case. The basal cell proliferation was found in an area of postatrophic hyperplasia (hyperplastic atrophy).

small acini adenocarcinoma may be addressed by noting the multilayering of the basal cells in the atypical basal cell hyperplasia and as well with use of antibodies that are reactive with high molecular weight cytokeratins, such as $34 \beta \mathrm{E} 12$. The small, solid nests of basal cell hyperplasia should not be confused with the solid growth of invasive, neoplastic prostatic epithelial cells because this is usually high-grade (Gleason Pattern 5) carcinoma that is sheet-like and solid. Also, high-grade carcinoma cells are cytologically much more atypical than the hyperplastic basal cells. Transitional cell carcinoma in the prostate can exhibit solid growth as small, rounded aggregates when it extends as an intraductal or intraacinar growth in the prostate, but these malignant cells are typically quite pleomorphic. Cribriform basal cell hyperplasia could be initially worrisome for prostatic intraepithelial neoplasia or carcinoma, but the bland basaloid cells do not appear to be neoplastic at high-power magnifications. Non-cribriform basal cell hyperplasia is readily confused with prostatic intraepithelial neoplasia, particularly low-grade prostatic intraepithelial neoplasia, but in prostatic intraepithelial neoplasia the nuclear abnormalities are in the luminal cells, and the basal cells should appear unremarkable. Other

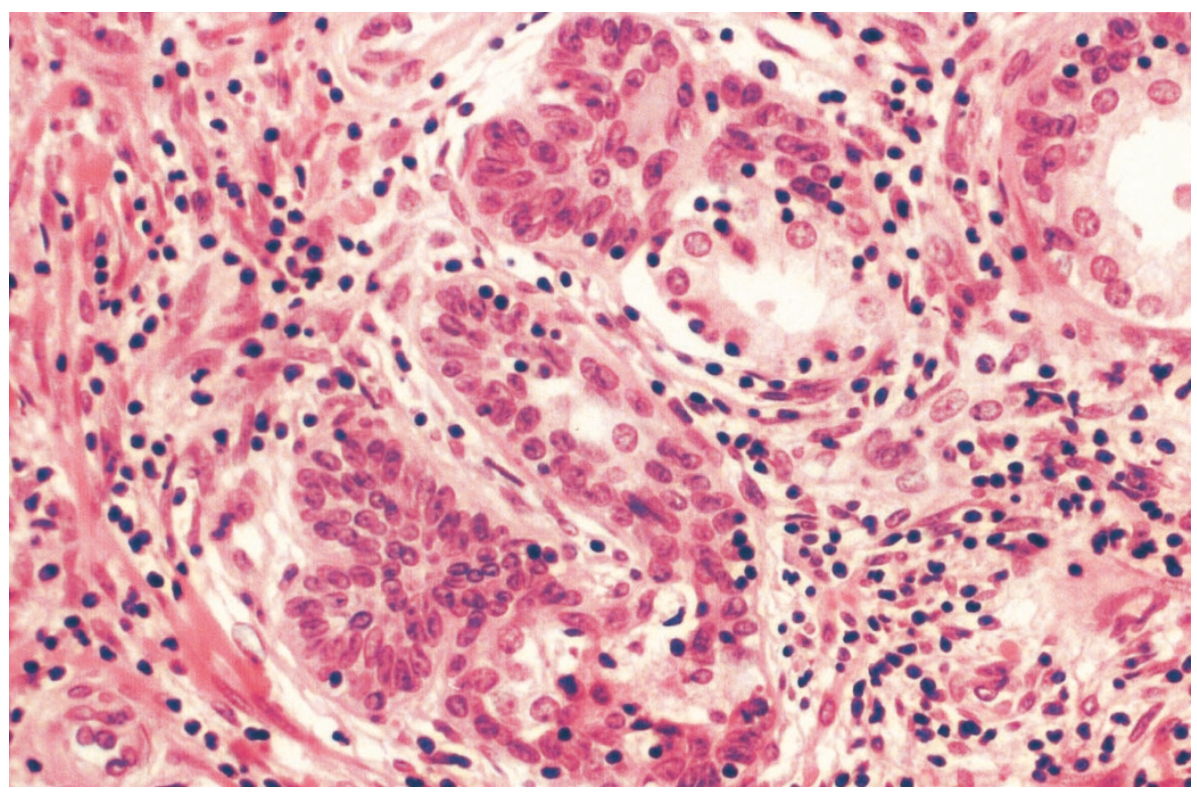

FIGURE 8. Basal cell hyperplasia in the transition zone in radical prostatectomy tissue. A lymphocytic infiltrate is present. 
TABLE 2. Mean Proliferation Index (PI) and Apoptotic Index (AI) of Normal Basal Cells Compared to Hyperplastic Basal Cells

\begin{tabular}{clll}
\hline Basal Cell Location & \multicolumn{1}{c}{ Status } & $\begin{array}{c}\text { Mean PI } \\
\text { (Range) }\end{array}$ & $\begin{array}{c}\text { Mean AI } \\
\text { (Range) }\end{array}$ \\
\hline Transition zone & Normal & $0.14(0-1)$ & $0.7(0-1.3)$ \\
Peripheral zone & Normal & $0.24(0-1)$ & $0.8(0-1.3)$ \\
Transition zone & Hyperplastic & $1.1(0-3.3)$ & $0.07(0-0.3)$ \\
Peripheral zone & Hyperplastic & $0.9(0-3.3)$ & $0.07(0-0.3)$ \\
\hline
\end{tabular}

Indices are given as percentage of MIB-1 positive cells (proliferation index) or percentage of TUNEL-positive cells (apoptotic index).

prostatic basal cell proliferations that should be in one's differential diagnostic checklist include basal cell adenoma, adenoid basal cell tumor, also known as adenoid cystic tumor, adenoid cystic-like tumor, adenoid cystic carcinoma, and basal cell carcinoma. Use of bcl-2 and Ki-67 immunostains can help separate basal cell hyperplasia from the rare basaloid carcinomas that occur in the prostate (9).

There is no currently available evidence to suggest that basal cell hyperplasia, with or without nucleoli, is a precursor proliferation for high-grade prostatic intraepithelial neoplasia or carcinoma $(2$, 4). For basal cell hyperplasia arising in the peripheral zone, the most common anatomic location in the prostate for development of prostatic intraepithelial neoplasia and carcinoma, we did not identify physical continuity between basal cell hyperplasia and high-grade prostatic intraepithelial neoplasia or carcinoma. Additionally, we found that the presence of basal cell hyperplasia in peripheral zone needle biopsy tissue was significantly associated with the absence, rather the presence, of adenocarcinoma. Clinical follow-up of one series of 14 patients with basal cell hyperplasia did not show evidence of development of prostatic carcinoma (2). In our series, for 26 patients with basal cell hyperplasia in peripheral zone needle biopsy and available clinical follow-up, only 3 were subsequently diagnosed with adenocarcinoma in four years of followup. This frequency was less than that for patients with benign prostatic tissue without basal cell hyperplasia (data not shown). These follow-up data from two series, albeit based on a low number of cases, support the notion that basal cell hyperplasia is not a precursor or risk factor for subsequent detection of carcinoma.

Peripheral zone and transition zone basal cell hyperplasia were similar in proliferation and apoptotic indices. The proliferation index was low, at about $1 \%$ for hyperplastic basal cells. This value is somewhat lower than the $2.7 \%$ (9) to $3.2 \%$ (27) previously reported for proliferation index of hyperplastic basal cells in two studies, but it is similar to the $1.4 \%$ figure obtained in a third study (28). In our series, hyperplastic basal cells had a significantly higher proliferation index compared with normal basal cells. Of interest, hyperplastic basal cells also had a lower apoptotic index than normal basal cells, suggesting that the increased cell numbers found in basal cell hyperplasia may be due to coordinate increase in proliferation index and decrease in apoptosis relative to normal basal cells of the prostate (28). In the future, it would be of interest to characterize gene expression profiles in normal versus hyperplastic basal cells to assess for perturbations in cell proliferation and cell death pathways (29). Increased bcl-2 expression in hyperplastic versus normal basal cells (28) suggests that focus on members of this anti-cell death protein family may be warranted. Given that inflammation is so commonly detected in foci of basal cell hyperplasia, it would also be of interest to experimentally test whether lymphocytes are capable of inducing basal cell proliferation and hyperplasia in the prostate.

In summary, basal cell hyperplasia may be incidentally detected in the peripheral zone of the prostate. These hyperplastic basal cells do not appear to represent a neoplastic precursor. The importance of peripheral zone basal cell hyperplasia in the prostate resides mainly in diagnostic recognition, where basal cell hyperplasia should be included in the differential diagnosis with high-grade prostatic intraepithelial neoplasia and carcinoma.

Acknowledgments: The authors thank Margaret Chesney for expert assistance in assembling the manuscript.

\section{REFERENCES}

1. Cleary KR, Choi HY, Ayala AG. Basal cell hyperplasia of the prostate. Am J Clin Pathol 1983;80:850-4.

2. Bennett BD, Gardner WA Jr. Embryonal hyperplasia of the prostate. Prostate 1985;7:411-7.

3. Golomb J, Lewin KJ. Basal cell hyperplasia of prostate: an elusive lesion? Urology 1992;40:245-8.

4. Epstein JI, Armas OA. Atypical basal cell hyperplasia of the prostate. Am J Surg Pathol 1992;16:1205-14.

5. Devaraj LT, Bostwick DG. Atypical basal cell hyperplasia of the prostate. Immunophenotypic profile and proposed classification of basal cell proliferations. Am J Surg Pathol 1993; 17:645-59.

6. Van de Voorde W, Baldewijns M, Lauweryns J. Florid basal cell hyperplasia of the prostate. Histopathology 1994;24:341-8.

7. Grignon DJ, Ro JY, Ordoñez NG, Ayala AG, Clearly KR. Basal cell hyperplasia, adenoid basal cell tumor, and adenoid cystic carcinoma of the prostate gland. An immunohistochemical study. Hum Pathol 1988;19:1423-33.

8. Sarma DP, Guileyardo JM. Basal cell hyperplasia of the prostate. J La State Med Soc 1982;134:23-4.

9. Yang XJ, McEntee M, Epstein JI. Distinction of basaloid carcinoma of the prostate from benign basal cell lesions by using immunohistochemistry for bcl-2 and Ki-67. Hum Pathol 1998;28:1447-50.

10. Rioux-Leclercq NC, Epstein JI. Unusual morphologic patterns of basal cell hyperplasia of the prostate. Am J Surg Pathol 2002;26:237-43. 
11. Young RH, Srigley JR, Amin MB, Ulbright TM, Cubilla AL. Prostatic hyperplasia. In: Tumors of the prostate gland, seminal vesicles, male urethra, and penis. Atlas of tumor pathology. 3rd ed. Washington, DC: Armed Forces Institute of Pathology; 1998. p. 54-60.

12. Dermer GB. Basal cell proliferation in benign prostatic hyperplasia. Cancer 1978;41:1857-62.

13. Mittal BV, Amin MB, Kinare SG. Spectrum of histological lesions in 185 consecutive prostatic specimens. J Postgrad Med 1989;35:157-61.

14. Mostofi FK, Sesterhenn IA, Davis CJ Jr, editors. Histological typing of prostate tumours. Berlin: Springer; 2002. p. 25.

15. Vaillancourt L, Têtu B, Fradet Y, Dupont A, Gomez J, Cusan $\mathrm{L}$, et al. Effect of neoadjuvant endocrine therapy (combined androgen blockade) on normal prostate and prostatic carcinoma. A randomized study. Am J Surg Pathol 1996;20:86-93.

16. Young RH. Pseudoneoplastic lesions of the urinary bladder, prostate gland, and urethra. In: Wick MR, Humphrey PA, Ritter JH, editors. Pathology of pseudoneoplastic lesions. Philadelphia, PA: Lippincott-Raven; 1997: 233-5.

17. Bostwick DG, Cheng L. Overdiagnosis of prostatic adenocarcinoma. Semin Urol Oncol 1999;17:199-205.

18. Shuman BA, Cohen JK, Miller RJ Jr, Rooker GM, Olson PR. Histological presence of viable prostatic glands on routine biopsy following cryosurgical ablation of the prostate. J Urol 1997;157:552-5.

19. Têtu B, Srigley JR, Boivin J-C, Dupont A, Monfette G, Pinault $\mathrm{S}$, et al. Effect of combination endocrine therapy (LHRH agonist and flutamide) on normal prostate and prostatic adenocarcinoma. A histopathologic and immunohistochemical study. Am J Surg Pathol 1991;15:111-20.

20. Armas OA, Aprikian AG, Melamed J, Cordon-Cardo C, Cohen DW, Erlandson R, et al. Clinical and pathobiological effects of neoad- juvant total androgen ablation therapy on clinically localized prostatic adenocarcinoma. Am J Surg Pathol 1994;18:979-91.

21. Van de Voorde WM, Elgamal AA, Van Poppel HP, Verbeken EK, Baert LV, Lauweryns JM. Morphologic and immunohistochemical changes in prostate cancer after preoperative hormonal therapy. A comparative study of radical prostatectomies. Cancer 1994;74:3164-75.

22. Grignon DJ, Sakr WA. Histologic effects of radiation therapy and total androgen blockage on prostate cancer. Cancer 1995;75:1837-41.

23. Montironi R, Schulman CC. Pathological changes in prostate lesions after androgen manipulation. J Clin Pathol 1998;51: $5-12$.

24. Sheaff MT, Baithun SI. Effects of radiation on the normal prostate gland. Histopathology 1997;30:341-8.

25. Reuter VE. Pathological changes in benign and malignant prostatic tissue following androgen deprivation therapy. Urology 1997;49(Suppl 3A):16-22.

26. Gaudin PB, Zelefsky MJ, Leibel SA, Fuks Z, Reuter VE. Histopathologic effects of three-dimensional conformal external beam radiation therapy on benign and malignant prostate tissues. Am J Surg Pathol 1999;23:1021-51.

27. Montironi R, Magi Gallazzi C, Diamanti L, Giannulis I, Pisani E, Scarpelli M. Prostatic intraepithelial neoplasia: expression and location of proliferating cell nuclear antigen in epithelial, endothelial and stromal nuclei. Virchows Arch 1993;422: 185-92.

28. Kyprianou N, Tu H, Jacobs SC. Apoptotic versus proliferative activities in human benign prostatic hyperplasia. Hum Pathol 1996;27:668-75.

29. Liu AY, Nelson PS, van den Engh G, Hood L. Human prostate epithelial cell-type cDNA libraries and prostate expression patterns. Prostate 2002;50:92-103. 